\title{
Why Tourism Regulation Matter to Sustainable Marine Tourism? Lesson Learnt from Berau Regency, East Borneo Province, Indonesia
}

\author{
Anugrah Adiastuti ${ }^{1}$, Heri Hartanto ${ }^{2}$, Adriana Grahani Firdaussy ${ }^{3}$ \\ ${ }^{I}$ Department of International Law, Faculty of Law, Universitas Sebelas Maret, Surakarta, Indonesia \\ ${ }^{2}$ Department of Procedural of Law, Faculty of Law, Universitas Sebelas Maret, Surakarta, Indonesia \\ ${ }^{3}$ Department of Constitutional Law, Faculty of Law, Universitas Sebelas Maret, Surakarta, Indonesia
}

\begin{abstract}
The development of tourism especially in marine tourism has been rocketed steadily year by year. This situation also happened in Indonesia. Supported with vast territory, oceans are central for Indonesia prosperity's because it captures fisheries and aquaculture activities, tourism industries and activities, including marine transportation and construction. Even though the income from tourism sector is quite promising but there is a widespread consensus that tourism growth especially in marine tourism should be sustainable. A number of threats that marine tourism shall be sustained, for instance unoptimized fisheries management, human impacts to coral reefs, substantial loss of mangroves especially in coastal development area, and the crucial thing about waste and plastic litter which impacts to ecosystems, community, and all related sectors. This writing analyse on the necessity of tourism regulation that matter to sustainable marine tourism. This research uses normative legal research which is a research design that examines the aspect of theories, concepts, legal principles, and regulations/legislations where relate to certain topics of this research which mainly focus in analyzing the matter of existing regulation to maintain the implementation of sustainable marine tourism in Berau Regency, East Borneo Province. Tourism regulation is required for sustainable tourism because it endows certainty on environmental protection, as legal basis for government officers/agencies in conducting action prevention and repressive action in connection with law enforcement, provide legal certainty on authority sharing between central government and regional government, and prevent overlapping jurisdiction but alongside each other making synergy and coordination must be held by inter and intra institution. As result, regulation either from central government and/or regional government, on marine tourism especially in Berau Regency, contributes to the obedience and law enforcement of to all parties who are interconnected to tourism sector.
\end{abstract}

Keywords: Tourism, Regulation, Marine and Coastal, Sustainable Tourism, Tourism Development.

\section{INTRODUCTION}

$\mathrm{T}$ ourism industry has emerged as substantial force for global sustainable socio-economic development [1]. There are two types of tourism based on the geographical condition, terrestrial/ land tourism and ocean/marine \& coastal tourism. For the development of tourism especially in marine tourism, it has been rocketed steadily year by year. Refer to the data and vision issuance by UNWTO, the number of
International Tourist Arrivals between 1950-2030, there was significant change since 2010 for tourism activities especially in Asia and Pacific regions and European regions [2]. It is shown on the data in Table. 1.

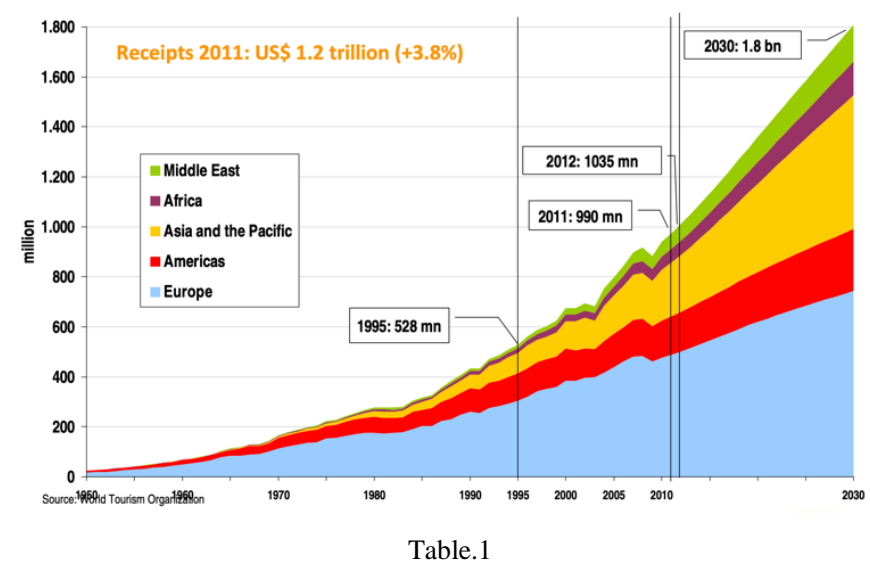

Source: UNWTO

From the data and the tourist projection, we know that the growth of tourism cannot be disregarded.

The similar situation also happened in Indonesia. As the largest archipelagic states in the world [3], Indonesia has a great opportunity in creating and utilizing the ocean territory to enlarge the national income from marine tourism.

Supported with vast territory, oceans are central for Indonesia prosperity's because it captures fisheries and aquaculture activities, tourism industries and activities, including marine transportation and construction. In 2019, the data showed that tourism sector contributed to US\$ 21 billion to GDP for either marine and non-marine, and in 2016, almost 50 percent foreign tourists always took part of marine and coastal activities during their trip to Indonesia [4].

Even though the income from tourism sector is quite promising but there is a widespread consensus that tourism growth especially in marine tourism should be sustainable [5]. There are a number of threats that marine tourism shall be sustained, for instance unoptimized fisheries management, human impacts to coral reefs, substantial loss of mangroves 
especially in coastal development area, inadequate infrastructure and unbalanced visitors between carrying capacity and capacity at the tourism location, and also the crucial thing about waste and plastic litter which impacts to ecosystems, community, and all related sectors.

Unoptimized fisheries management in Indonesia caused by overfished activity around $38 \%$ in 2017, and many unmonitored and unregistered vessels that incursion to Indonesia water [6]. Human activities may harm the coral reefs either from recreational or tourism agenda (such as using fin during snorkel in coral reef $\mathrm{s}$ area) or fisheries (using bomb or prohibited tools to catch the fish and ocean creatures). These actions lead to the damage of coral reefs, while the existing coral reefs are taking part in generating oxygen to nature and as the source of food and habitation for fishes.

Unequal development in coastal area also may cause the unbalancing calculation how the area may carry all tourists who come at the same time and how many volume of waste or litter that can be tolerance by the area capacity. This situation should be anticipated because it also impacts on the living mangroves in coastal areas.

In Berau Regency, especially marine tourism sector, some places have regulated certain conditions for marine tourism activities and many of them have not considered or made the regulation on sustainable marine tourism.

\section{RESEARCH QUESTION}

According to the introduction given above, the writers intend to put in writing and the main research question in this writing:

- Why tourism regulation matter to sustainable marine tourism?

\section{LITERATURE REVIEW}

\section{Sustainable Marine Tourism}

Marine tourism is one kind of support of land tourism [7]. According to Mark Orams, marine tourism is a recreational activity that involves travelling from one place to other places and they have their host to focus on marine environment. While Hall, he mentions that marine tourism including coastal tourism have to entail shore-based activities. The activities in marine and coastal areas help to boost the economic value and growth of the oceans. Economic values coming from marine tourism may vary from all resources such as historical, educational, cultural, infrastructure, natural). Therefore, most successful tourist destination shall determine their most potential tourist attraction [8].

The establishment of tourist attraction in tourism destination has significant role in making multiplier effect. The multiplier effect itself, is not only related to natural resources and natural resources but also the creation of new job opportunities. Multiplier effect in tourism sector cannot be detached with tourism indicators. There are several indicators for sustainable marine tourism. They are natural resources, infrastructure, accessibility, culture, social involvement and employment, institution, security and comfort, socio-economy, change of investment, tourism management policy, and branding and promotion [9].

- Natural resources as first indicator have considerable part for tourism development starts from management, marine and coastal ecosystem protection, processing marine resources, and strengthening marine and coastal community.

- Infrastructures, related to marine tourism, shall meet the minimum standards that guarantees the convenience and safety for tourist satisfaction. It includes the basic forms, such as roads, electricity, water supply, transportation (ports/harbors/airports/terminals/stations), public facilities (banks, ATMs, gas stations), tourism facilities (hotels/resorts, guest houses, information centers) and health facilities.

- The third indicator is accessibility. It is an important indicator for tourist to visit tourism destination which is influenced by the existing facilities to reach out their destinations. The higher and the better facilities boost tourist fulfillment and at the same time it more contributes the sense of achievement of tourism management.

- Fourth, culture has influences to make distinct character for tourist destination compared to other destinations. Specific culture such as certain living law or ceremony that is still done frequently may attract the raise number of tourist to come.

- Social involvement and employment usually involve participation of local people in tourism management of new members of the community is limited to being a worker and a small number become owners of tourist facilities such as restaurant, home-stay or resort owners. Most tourism management is carried out by local governments and private parties. To support the development of sustainable marine tourism, the community within the area must be alert to environment issue such as waste and also aware to the improvement of language and work skills.

- Institution as part of tourism indicator may come from central government and/or municipal government. This is associated with regulation and sometimes policy that shall be taken in order to foster tourism activity.

- For security and comfort indicator, it is obtained because public awareness that plays an active role in protecting tourists who come if tourists experience difficulties such as experiencing loss of public goods will be very helpful. Visitors' comfort is also supported by public awareness not to disturb visitors with hawkers.

- Socio-economic activities related to tourism, for example stall business, lodging, transportation 
services, rental by beach sports equipment, tour guides, and travel agents. Because tourism sector especially in marine tourism destinations, in Berau Regency, are a leading sector that is quite high in demand, most people assume that the tourism sector is a sector that is able to sustain the lives of local people, so that people are expected to be more prosperous and the level. This assumption shall be guided with prior preparation training for other skills to avoid unprecedented situation that might happen in the future.

- Most of tourism locations in Berau Regency have stunning and beautiful natural scenery and landscape and this can be used to allure the change of investment domestically or from overseas. The number of new investment or at least the raise of capital from existing investors could increase better hospitality and enlarge tourism attraction for tourists.

- Tourism management policies are urgently needed to provide direction for tourism development so that all stakeholders, especially the community, can play an active role in the development of marine tourism.

- Last, branding and promotion as tourism indicator has an important role to embrace more tourists to come to Berau Regency enjoying marine tourism. This activity should be made in systemic manner and comprehensive promotion involving not only stakeholder but also community and respected influencer who can promote the marine tourism destinations in splendid plans and steps.

\section{Tourism Regulation in Indonesia}

In Indonesia, tourism sector is governed under the Ministry of Tourism and Creative Economy of the Republic of Indonesia (Kementerian Pariwisata dan Ekonomi Kreatif republik Indonesia). The structure of organization [10] can be seen at Table. 2 as follow:

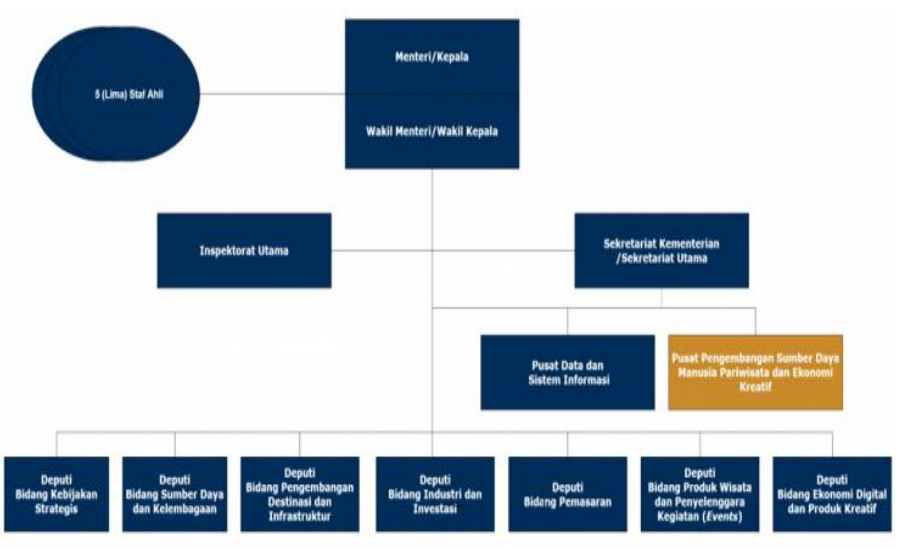

Table. 2

Source: Ministry of Tourism and Creative Economy of the Republic of Indonesia
Tourism activities located in Indonesia's territory shall refer to the regulation issued by the Ministry of Tourism and Creative Economy. Several main regulations on tourism sector are Law Number 10 of 2009 on Tourism (UndangUndang-Undang Nomor 10 Tahun 2009 tentang Pariwisata); Law Number 23 of 2014 on Regional Government (UndangUndang Nomor 23 Tahun 2014 tentang Pemerintahan Daerah); Presidential Regulations at Regulation of The President of the Republic of Indonesia Number 40 of 2017 on the Amendment to Number 64 of 2014 on Strategic Coordination on Cross Tourism Sector (Peraturan Presiden Nomor 40 Tahun 2017 tentang Perubahan atas Peraturan Presiden Nomor 64 Tahun 2014 tentang Koordinasi Strategis Lintas Sektor Penyelenggaraan Kepariwisataan); Ministerial Regulation at Regulation of The Minister of Tourism of the Republic of Indonesia Number 10 of 2016 on Integrated Tourism Master Plan for Regional Government (Provincial, Regency and Municipal Government) (Peraturan Menteri Pariwisata Nomor 10 Tahun 2016 tentang Pedoman Penyusunan Rencana Induk Pembangunan Kepariwisataan Provinsi dan Kabupaten/Kota); Regulation of The Minister of Tourism of the Republic of Indonesia Number 14 of 2016 on Sustainable Tourism Destinations Handbook (Peraturan Menteri Nomor 14 Tahun 2016 tentang Pedoman Destinasi Pariwisata Berkelanjutan).

Regulating tourism activities in Indonesia even though mostly regulated under Ministry of Tourism and Creative Economy of the Republic of Indonesia but it is not only limited to this ministry. Besides above regulations, tourism actors and business owner shall also deal with other regulations from other institutions or ministries such as Ministry of Marine Affairs and Fisheries, Ministry of Environment and Forestry, and some agencies or office in regional government (provincial government/municipal government). For any regulation related to tourism in each region in Indonesia, usually regional government have made their Provincial/Regency/Municipal Integrated Tourism Master Plan and its implementing regulations completed with their specific characteristic of their tourism destinations.

\section{METHOD \\ 1. Research Design}

This writing used normative legal research which was a research design that examines the aspect of theories, concepts, legal principles, and regulations/legislations where relate to certain topics of this research. This legal research used documents, such as law as the secondary data, which was then followed by general explanations and data in the field or to the community with government regulation. The normative juridical research design was shown to the legal language by looking at the implementation of the law to the laws and regulations concerning between central government and municipal governments, especially sustainable marine tourism. This research was located in Berau Regency, East Borneo Province, Indonesia. This writing mainly focused in analyzing the matter of existing regulation to maintain the 
implementation of sustainable marine tourism in Berau Regency, East Borneo Province.

\section{Sources of Data}

The sources of the data in this study was obtained by the researcher. Secondary data sources were obtained indirectly where consisted of three categories, namely literature/documentation study techniques, observation, and media analysis. The first category was the study of documentation in the form of documents originating from primary legal materials. The second category was the observation of the explanation of legal materials, opinions of experts, legal practitioners, and relevant previous research. The third category was the data, which is then analysed, from the particular institution in Berau Regency related to sustainable marine tourism such as Environmental Office of Berau Regency, Fisheries Office of Berau Regency, Tourism Office of Berau Regency, and tourism actors.

\section{Data Collection}

Data collection purposed to ensure the completeness of research information data carried out by the research analysis unit in the form of a document of national legal regulations concerning sustainable marine tourism. Data collection was carried out by reviewing national legal rules and regulation issued by municipal government using data collection criteria. In conducting data collection, researchers studied and established identification criteria to select relevant laws and regulations, namely those related to marine law, tourism law, and environmental law. The researcher selected data from each derived data source by identifying the data criteria for the rule of law that had been grouped according to the research topic and linking them to the source of data.

\section{Analysis of Research Materials}

Legal materials will be analysed in stages according to problem. The analysis was carried out in the form of a description (descriptive-analytic) which contained activities which describe, analyse, systematize, interpret, and evaluate.

\section{ANALYSIS}

Besides mining particularly on coal and palm oil plantation, tourism sector is one of the top three economic activity and income in Berau Regency. In Berau Regency, East Borneo Province, there are so many existing regulations associated to tourism sector, but this writing will only focus on certain regulations such as Berau Regency Regulation Number 9 of 2017 on Berau Regency Spatial Planning year 2016-2031 (Peraturan Kabupaten Berau Nomor 9 Tahun 2017 tentang Tata Perencanaan Wilayah tahun 2016-2036); Berau Regency Regulation Number 3 of 2018 on Berau Regency Integrated Tourism Master Plan Year 2016-2031 (Peraturan Kabupaten Berau Nomor 3 Tahun 2018 tentang Rencana Induk Kepariwisataan Tahun 2016-2031); Berau Regency Regulation Number 16 of 2019 on the Protection oof Shark, Manta Rays, certain fishes and Coral Reefs (Peraturan
Kabupaten Berau Nomor 16 Tahun 2019 tentang Perlindungan Ikan Hiu, Ikan Pari Manta, Jenis Ikan tertentu dan Terumbu Karang); Governor Decree of East Borneo Province Number 253.13/K.103/2018 on Task Force Establishment on Coastal Protected Areas Management and small island and surrounded water in Derawan Islands (Keputusan Gubernur Kalimantan Timur 253.13/K.103/2018 tentang Pembentukan Satuan Tugas Pengelolaan Kawasan Konservasi Pesisir dan Pulau-Pulau Kecil Kepulauan Derawan dan perairan sekitarnya di Kabupaten Berau); Regent Decree of Berau Number 886 of 2015 on Governance Establishment of Derawan Destination Management Organization; Regent Decree of Berau Number 101 of 2017 on Working Group Establishment of Berau Regency Tourism Development Acceleration in 2017 (Keputusan Bupati Berau Nomo 101 Tahun 2017 tentang Pembentukan Tim Pokja Percepatan Pembangunan Pariwisata Daerah tahun Anggaran 2017); Regent Decree of Berau Number 709 of 2017 on Arrangement of Mina Bestari Fishing Village Location on Derawan islands (Keputusan Bupati Berau Nomor 709 Tahun 2017 tentang Penetapan Lokasi Kawasan Pedesaan Perikanan Mina Bestari, Kecamatan Pulau Derawan).

Before analyse further on East Borneo Province and Berau regency regulations, author firstly analyse tourism regulation issued by Minitstry of Tourism and Creative Economy of the Republic of Indonesia and related ministries.

1. Central Government Regulation of the Republic of Indonesia

a. Law Number 10 of 2009 on Tourism (UndangUndang Nomor 10 Tahun 2009 tentang Pariwisata) Under this regulation, the Government of Indonesia (GoI) assures that tourism is an essential development where is conducted systemically, well planned, integrated and prolonged. An explicit ruling has been written under this law and from the substance, it is also ensure that tourism development shall follow and pay attention to environmental aspect. Furthermore, there is also an obligation that tourism activities shall concentrate on preserved environment.

One out of four tourism development [11] is tourism institution which includes government, private sector, society, tourism regulation and mechanism where rights and obligations are binding to them. Government institution in here means Ministry of Tourism and Tourismm Office in Provincial and Regency level, including the issuance of tourism regulation and policy. Meanwhile, private sector are any business sectors that held tourism activities such as hotels, restaurant, tourism services, and so on. For society, it usually comes from Travel Awareness Group or in Indonesia language called as Kelompok Sadar Wisata (POKDARWIS).

Therefore, every right and obligation implementation conducted by the tourism actor, 
institutions, business owner must stay with the concept of sustainable tourism as stated at Article 2 and 4 Law Number 10 of 2009 on Tourism.

b. Law Number 32 of 2009 on Environmental Protection and Management (Undang-Undang Nomor 32 Tahun 2009 tentang Perlindungan dan Pengelolaan Lingkungan Hidup)

Every action by human being and nationals, states, any legal subject in Indonesia territory shall obey and ensure that their any action refer to environmental principles and one of them is preservation and sustainability [12].

Under this law, even there is no explicit clause which orders and directly connects to tourism, but it is visible that protection and management in environment is needed in order to prevent any degradation condition in terrestrial or marine areas. This means that any action related to tourism activities must consider the preventive impact and at the same time strengthen the continuity of ecosystem.

c. Law Number 23 of 2014 on Regional Government (Undang-Undang Nomor 23 Tahun 2014 tentang Pemerintahan Daerah)

It is stated that regional government jurisdiction is delegated from central government and under concurrent governance every regional government has their own authority [13].

Concurrent governance intend to divide the jurisdiction, task and function, but concomitantly they have synergy and coordination in handling particular sector.

On top of that, the giving administration on tourism sector has been ruled under concurrent governance as mentioned at Article 12 Section 3 point $b$ and followed with detail for each type of governance in Annex $Z$ point 1, 2, 3 and 4 Law Number 23 of 2014 on Regional Government. This distinguish authority is quite helpful for institutions under the same vertical hierarchy, but in fact (sometimes) it creates overlapping and even misinterpretation with other agencies or offices due to interconnected area and responsibility of tourism activities.

d. Law Number 32 of 2014 on Marine and Fisheries (Undang-Undang Nomor 32 Tahun 2014 tentang Kelautan dan Perikanan)

Tourism growth, under this law, is clearly expressed that each government (central and regional) under their particular jurisdiction facilitates the enlargement of tourism prospect in accordance with sustainable tourism, local wisdom, and marine protected areas [14]. It is transparent that each governance accountable in managing tourism sector, tourism activities with its distinction. Marine tourism development is enhanced under the criteria of Marine Zonation Management Plan (in Indonesia it is called as Rencana Pengelolaan Zonasi
Perairan/RPZ Perairan) where there are certain zones that can be used for tourism activities while other (such as Core Zone (in Indonesia language stated as Zona Inti) is totally prohibited for tourism.

e. Regulation of The President of the Republic of Indonesia Number 40 of 2017 on the Amendment to Number 64 of 2014 on Strategic Coordination on Cross Tourism Sector (Peraturan Presiden Nomor 40 Tahun 2017 tentang Perubahan atas Peraturan Presiden Nomor 64 Tahun 2014 tentang Koordinasi Strategis Lintas Sektor Penyelenggaraan Kepariwisataan)

In this regulation, it noticeably governs that Tourism coordination Team consists and includes Ministry of Environment and Forestry. It signifies that tourism activities do not only concentrate to tourism but also it has proportion part to environmental aspect [15]. This proportion implementation can be seen with the involvement from other agencies such as Environmental Office that has authority in ensuring that tourism development must calculate the capacity and carrying capacity including it does not violates the boundary of protected areas.

The implementation of ecotourism which is linked to nature tourism in natural protected areas enthusiastically to be used for nature conservation at the long-term. It produces greener tourism industry with ecological and social-cultural awareness behaviour of society and tourists [16].

f. Regulation of The Minister of Tourism of the Republic of Indonesia Number 10 of 2016 on Integrated Tourism Master Plan for Regional Government (Provincial, Regency and Municipal Government) (Peraturan Menteri Pariwisata Nomor 10 Tahun 2016 tentang Pedoman Penyusunan Rencana Induk Pembangunan Kepariwisataan Provinsi dan Kabupaten/Kota)

Strategy in creating tourism destination development must consider the impact of tourism enlargement either in short-term, medium term or long-term stages. Program and plan of actions, program effectuation, supervision, and evaluation are arranged in sequence in order to assess the balance of carrying capacity and capacity of the environment to cope with tourism activities. Carrying capacity must reckon physical, social, and economy ability of the region or tourism location [17]. Running fresh tourism strategy is one approach to expand the number of tourists (domestic and international) to come to tourism destination. Aside from conventional way, recent set of tactics such as smart tourism might contribute to augment the considerable tourists [18].

To support conventional and recent tourism strategy, a change of mindset cannot be push aside. A same vision to reach better tourism growth should be bear in mind not only for stakeholder but also society and 
business owner in tourism sector. The form of mindset includes the means to acquire people's prosperity and quality of life, set long-term tourism goals with a definite vision and mission, allocate well proportion between international tourism and domestic tourism, transfer and control of tourism must be executed properly in line with regulation and policy that has been/will be made [19].

g. Regulation of The Minister of Tourism of the Republic of Indonesia Number 14 of 2016 on Sustainable Tourism Destinations Handbook (Peraturan Menteri Nomor 14 Tahun 2016 tentang Pedoman Destinasi Pariwisata Berkelanjutan)

The scope of tourism controls environmental sustainability. From the consideration part, annex, and the main clause of the regulation Article 3, tourism destination shall be formed in sustain way [20]. The stressing point of sustainability is to confirm that climate adaptation shall be carried out. De-escalation of risk must calculate the source of light and noise disturbance, waste. What is more, interception and supervision are important to examine the environmental harm and destruction what kind of solution that should be taken into account.

2. Regional Government Regulation (Berau Regency, East Borneo Province, Indonesia)

a. Regency Regulation Number 9 of 2017 on Berau Regency Spatial Planning year 2016-2036 (Peraturan Daerah Kabupaten Berau Nomor 9 Tahun 2017 tentang Rencana Tata Ruang Wilayah Kabupaten Berau Tahun 2016-2031)

Berau Regency states their regions will focus to evolve in two things: industry and tourism competitively and sustainably. Furthermore, any policy incorporated to tourism shall be based on sustainability principle [21]. Marine tourism in Berau regency comcentates on 4 locations: Derawan islands, Maratua, Biduk-biduk and Batu Putih.

Tourism activities should also calculate possibility of ocean water infiltration to the land and (might) affect the quality of groundwater, including the usage of natural potentiality should anticipate carrying capacity and capacity at tourism destination.

b. Regency Regulation Number 3 of 2018 on Berau Regency Integrated Tourism Master Plan Year 2016-2031 (Peraturan Daerah Kabupaten Berau Nomor 3 Tahun 2018 tentang Rencana Induk Pembangunan Kepariwisataan Daerah Tahun 20162031)

Tourism Master Plan Establishment in Berau regency regulates the detail stage to enforce step by step tourism development completed with arrangement on tourism destination, marketing, industries, and institutions. Moreover, facilities, accessibility, control, and supervision are constructed as prepared by Berau Regency government [22]. Before tourism activities can be conducted, occasionally particular institutions or offices have to assure that the program can be directly utilized, but sometimes, some of them only can be done after implementing and technical regulation in Berau Regency have been made.

c. Regency Regulation Number 16 of 2019 on the Protection oof Shark, Manta Rays, certain fishes and Coral Reefs (Peraturan Daerah Kabupaten Berau Nomor 16 Tahun 2019 tentang Perlindungan Ikan Hiu, Pari Manta, Jenis Ikan Tertentu dan Terumbu Karang)

Refer to Consideration point a. and point $\mathrm{c}$. of this regulation, it regulates that the protection and management of Berau sea shall comply with preserved environment and sustainable biodiversity [23]. Consciousness on the function of ecology/ecosystem support to prosperous living marine natural resources. Moreover, to ensure nature tourism in line with particular environment principles, supervision and punishment must be enforce diligently and correctly.

d. Regent Decree of Berau Number 886 of 2015 on Governance Establishment of Derawan Destination Management Organization (Keputusan Bupati Berau Nomor 886 Tahun 2015 tentang Pembentukan Forum Tata Kelola Pariwisata DMO Derawan)

Derawan Destinationa Management Organization (Derawan DMO) has been decided since 2010 altogether with other 14 tourism destination under Minsitry of Tourism and Creative Economy of the Republic of Indonesia [24]. DMO in here is purposed to speed up the tourism destination development collaborate among academician, business, government, media, and the empowerment of community/society in Berau Regency.

Derawan DMO is carried out by team who is responsible and submit their working report to Ministry of Tourism and Creative Economy of the Republic of Indonesia, Governor of East Borneo Province and Regent of Berau [25].

e. Regent Decree of Berau Number 101 of 2017 on Working Group Establishment of Berau Regency Tourism Development Acceleration in 2017 (Keputusan Bupati Berau Nomor 101 Tahun 2017 tentang Pembentukan Tim Pokja Percepatan Pembangunan Pariwisata Daerah Tahun Anggaran 2017)

Task Force made under this decree obliges to collect data and information on tourism sector and other supporting sector to boost tourism growth, to make strategy, working targets, and solution yearly on tourism activities, and to assure a synergy between Berau Medium-Term Development Plan (Rencana Pembangunan Jangka Menengah Daerah/RPJMD Berau) and Berau Stratagic Plan (Renstra Berau) [26]. 
f. Regent Decree of Berau Number 709 of 2017 on Arrangement of Mina Bestari Fishing Village Location at County of Derawan islands (Keputusan Bupati Berau Nomor 709 Tahun 2017 tentang Penetapan Lokasi Kawasan Pedesaan Perikanan Mina Bestari (Perikanan yang Berdaya Saing dan Lestari) Kecamatan Pulau Derawan)

There 3 locations that are decided as the fihisng village under this decree, they are Derawan islands village, Kasai village and Semanting bay Village. The aim of fishing village initiation is to create and provide driving fishing products in a satisfactory result [27].

From earlier analysis refer to several regulations (nationally and regionally), a clear and definite regulation on tourism endows:

- A guarantee of certainty on environmental protection also has been stated at Article 12 Law Number 10 of 2009 on Tourism where the capacity and the carrying capacity of tourism must be environmentally informed and literate. In general point of view tourism sector has a link to environment which means directly-indirectly should accept more environmental principles. A similar ruling also has been written under Law Number Law Number 32 of 2009 on Environmental Protection and Management.

- Legal basis for government officers/agencies in conducting action prevention and repressive action in connection with law enforcement. This can be clearly seen at Article 23 Section 1 Law Number 10 of 2009 on Tourism.

- Legal certainty on authority sharing between central government and regional government (province, regency and/or municipal government) on specific field, problem, location that under their competence, jurisdiction and responsibility.

- Prevent overlapping jurisdiction but alongside each other making synergy and coordination must be held by inter and intra institution whose is responsible for each task given by the law.

\section{CONCLUSION}

From the analysis section, it can be concluded the making and issuing regulation either from central government and/or regional government, on marine tourism especially in Berau Regency, contributes to the obedience and law enforcement of to all parties who are interconnected to tourism sector. In some parts, implementation of tourism law is not as easy as our thought because it has various component from other sector, but it is visible that any tourism activities shall be handled under certain and transparent regulation.

\section{ACKNOWLEDGEMENT}

We would like to express our gratitude to Research Centre and Community Service Agency of Universitas Sebelas Maret
(Lembaga Penelitian dan Pengabdian Kepada Masyarakat Universitas Sebelas Maret) that had given us a research grant which support this publication, and thank to local government, Berau Regency and all of stakeholder and office that support in the research. Participating in this an important project has been a great pleasure.

\section{REFERENCES}

[1] Wakimin N., Azlinaa A., Hazman S. Tourism demand in Asean-5 countries: Evidence from panel data analysis. Manag. Sci. Lett. 2018;8:677-690. doi: 10.5267/j.msl.2018.4.023; Hwang J., Lee J. A strategy for enhancing senior tourists' well-being perception: Focusing on the experience economy. J. Travel Tour. Mark. 2019;36:314-329. doi: 10.1080/10548408.2018.1541776 www.unwto.org https://law.ui.ac.id/v3/the-role-of-indonesia-asthe-largest-archipelagic-state-in-the-world/

[2] World Bank (2021). Oceans for Prosperity: Reforms for a Blue Economy in Indonesia. The World Bank, Washington, D.C.

[3] Gössling S., Peters P., Ceron J.P., Dubois G., Patterson T., Richardson R.B. The eco-efficiency of tourism. Ecol. Econ. 2005;54:417-434. doi: 10.1016/j.ecolecon.2004.10.006

[4] Wang, L., \& Zhang, H. (2019). The Impact of Marine Tourism Resources Development on Sustainable Development of Marine Economy. Journal of Coastal Research, 589-592. https://www.jstor.org/stable/26854009

https://www.iora.int/media/23919/cios-prof-attri-presentation.pdf

[5] Rumiati, A. T., Gunawan, J., \& Ekasari, N., (2019). Developing Indicators to Measure Sustainable Marine Tourism Development Study Case: In Selong Belanak Village, West Praya, Central Lombok Province. PEOPLE: International Journal of Social Sciences, $\quad 5(2), \quad 833-847$. https://pusbangsdm.kemenparekraf.go.id/index.php/profil-singkat/

[6] Law of the Republic of Indonesia Number 10 of 2009 on Tourism.

[7] Law of the Republic of Indonesia Number 32 of 2009 on Environmental Protection and Management.

[8] Law of the Republic of Indonesia Number 23 of 2014 on Regional Government.

[9] Law of the Republic of Indonesia Number 32 of 2014 on Marine and Fisheries. Regulation of The President of the Republic of Indonesia Number 40 of 2017 on the Amendment to Number 64 of 2014 on Strategic Coordination on Cross Tourism Sector.

[10] Tonazzini, D., Fosse, J., Morales, E., González, A., Klarwein, S., Moukaddem, K., Louveau, O. (2019) Blue Tourism. Towards a Sustainable Coastal and Maritime Tourism in World Marine Regions. Edited by Eco-Union. Barcelona. Regulation of The Minister of Tourism of Republic of Indonesia Number 10 of 2016 on Integrated Tourism Master Plan for Regional Government.

[11] Dimas Y.N., et.al. (2019). "Smart Tourism Strategy in Increasing the Number of Tourist in Indonesia". Advance in Economics, Business and Management Research. Volume 65. Atlantis Press. pp. 149-154. DOI=https://doi.org/10.2991/icebef-18.2019.36.

[12] Ministry of Tourism and Creative Economy of the Republic of Indonesia in cooperation with International Labor Organization. (2012). "Strategic Plan Sustainable Tourism and Green Jobs for Indonesia". Indonesia. Regulation of The Minister of Tourism of the Republic of Indonesia Number 14 of 2016 on Sustainable Tourism Destinations Handbook. Regency Regulation Number 9 of 2017 on Berau Regency Spatial Planning year 2016-2036. Regency Regulation Number 3 of 2018 on Berau Regency Integrated Tourism Master Plan Year 2016-2031. Regency Regulation Number 16 of 2019 on the Protection oof Shark, Manta Rays, certain fishes and Coral Reefs. https://kemenparekraf.go.id/post/percepatan-pengembangandestinasi-wisata

[13] Regent Decree of Berau Number 886 of 2015 on Governance Establishment of Derawan Destination Management Organization.

[14] Regent Decree of Berau Number 101 of 2017 on Working Group Establishment of Berau Regency Tourism Development Acceleration in 2017. 
International Journal of Research and Innovation in Social Science (IJRISS) |Volume VI, Issue I, January 2022 |ISSN 2454-6186

[15] Regent Decree of Berau Number 709 of 2017 on Arrangement of Mina Bestari Fishing Village Location at County of Derawan islands. 